\title{
For a Workable Green Revolution for India
}

\author{
S Jeevananda Reddy* \\ Formerly Chief Technical Advisor, Telangana Academy of Sciences, India
}

Submission: February 03, 2018; Published: March 22, 2018

*Corresponding author: S Jeevananda Reddy, Formerly Chief Technical Advisor, Telangana Academy of Sciences, India, Email: Jeevananda_reddy@yahoo.com

Abstract

The note presents a brief accounting of agriculture in India to date and what is to be done for achieving an environment friendly workable green revolution or sustainable agriculture.

\section{Introduction}

Globalization is the process through which rich becomes richer and poor becomes poorer irrespective of where they live. The degree of this effect varies with the strengths in the areas of technology, logistics, infrastructures, and finally on the quality of governance. The process of globalization in agriculture is motivated by World Bank, International Monitory Fund, and all-powerful multinationals (MNCs) from the West. Most unfortunately, now even the UN Agencies also joined this bandwagon along with CGIAR, Oxfam, etc. Many a times Noble Prize legitimizing the bad research that serve the vested interests, is the cause of major ills of the society \& environment. Here it is pertinent to note what Mahatma Gandhi said "India has enough resources to fulfill everyone's need but it can't fulfill one person's greed".

History says that man has been on the Earth for approximately two million years. During $99 \%$ of the time he has lived as a hunter-gatherer. Only ten thousand years ago he started domesticating plants and animals and is living fewer than 300 years in an industrial society. Thus, the origin of agriculture was a gradual transition starting with the planting of few seeds of the most useful plants in the areas surrounding the gatherers' camp. As agriculture establishes, the struggle of man against certain plants, the specialization and selection of plants, started within a framework of his environment in terms of soil and climate. Vedic literature provides insight in to the earliest written records of agriculture in India - some such local reports are available all over the world also --. Rugveda hymns describe cultivation systems existing in India at that time of the history. Also, there are several other inscriptions/excavations that showed the ancient agriculture practices followed in those Eras in those areas.

\section{Sustainable food and nutrition security system}

The traditional agriculture was soil and climate driven farming systems that encompasses the animal husbandry. It provided socio-economic, food and nutrient security with the healthy food. Those were the "Golden Days" in the history of farming. It was an environment-friendly system and was highly successful \& sustainable. No pollution, no worry about seeds and fertilizer adulteration as they used good grain as seed and compost of farmyard manure and green manure as fertilizer. This system of agriculture was clouded by the chemical inputs agricultural technology in 1960s [1].

\section{Unsustainable food and nutrition security system}

Following the growth in population the food production balance got disrupted and in order to find a solution to ever growing problem, in 60s entered the chemical inputs mono crop technology in the form of much eulogized Green Revolution Technology. Later in 2002-03 entered genetically modified seed technology in to India. With the help of chemical input technology food security was achieved up to an extent. But, it came at huge costs with disastrous impact on environment [2].

India is an agrarian country providing employment directly or indirectly to around 60 percent of the rural population. On an average, around 65 percent of cultivated area is at the mercy of "Rain God" as areas under groundwater and surface water based irrigation compensating each others. The traditional technology was evolved over hundreds of years' experience of farmers in which climate change was a part; and whereas the green revolution technology was evolved over few years research farm experience with large yield gap between on farm and research station on the one hand and between dry-land and irrigated 
agriculture on the other hand. Climate change was not a part of it [3].

The Green Revolution Technology increased the production substantially in terms of quantity but failed to achieve the quality of traditional agriculture in terms of food and fodder. The technology includes high yielding seeds, chemical inputs (fertilizers \& pesticides, insecticides, herbicides, etc.) and irrigation. Thus it became most cost-ineffective technology. Even with heavy input subsidies, loan waivers schemes and minimum support prices, among other things, farmers' suicides are rampant while agricultural growth remains sluggish. Ironically, it is the middlemen who are reaping dividends.

\section{Highly hazardous technology}

Forty years later, genetically modified (GM) seed entered into Indian agriculture system. Most innovations in this have been profit-driven rather than need-driven. Global seed industry is controlled by four western MNCs and at the same time GM seed industry is in one MNC's hands. The GM technology responds to the need of GM companies to intensify farmers' dependence upon seeds protected by the so-called intellectual property rights, which conflicts directly with the age-old rights of farmers to reproduce, share or store seeds. In fact, to get overnight profits, the Indian seed companies changed their high yielding seed into GM seed with zero/negative yield advantage; and ensured that non-GM seed is "not sold in the market". This has resulted markets flooding with spurious/adulterated GM seed varieties under different names.

Bt-cotton, a GM seed, is in use since 2002-03 in India - even before approval, seed entered the farmers' fields. The area under Bt-cotton steadily increased and area under non-Bt decreased. Over-all area under cotton more than doubled under high input costs. As Bt-cotton was also grown under the same conditions of green revolution technology the yields have been more than doubled with high year to year variations due to climate and non-implementation of crop rotation.

Unfortunately the Bt- technology was short lived. In hardly 15 years, as Bt1 became ineffective, Bt2 was introduced. When this was also turned ineffective, they brought-in terminator technology, which was internationally banned [including UN] technology [Bollgaurd-II Roundup Ready Flex] and that too entered India illegally. Why I said illegally is, the seed company applied for government approval and later withdrew the application. While this illegality is going on, Bollgaurd-III Roundup Ready Flex entered India illegally. Laws won't apply to them.

Yet, the productivity has been stagnant for the past five years - in the case of green revolution technology it is stagnated since 1984-85 --. GM groups vigorously lobbied to introduce GM food crops but with the strong protests from the farmer groups the government has not cleared them for cultivation in India but yet they are being grown illegally as the four pillars of the Indian constitution are corrupt to the core.

\section{Newer agriculture technologies impact on environment}

Newer technologies were portrayed as a solution to all human problems, especially the problem of hunger and poverty forgetting their negative impacts on the environment in which air, water, soil \& food pollution are the major components that created severe \& widespread health hazards. This "western profit driven" chemical input mono crop technology was found to be more dangerous on long-term, over the short-term gains. FAO a UN body report states that around $30 \%$ of the produce is going as waste - this is more than $40 \%$ in India. Thus, to that extent the natural resources/inputs are going as waste. When this technology was introduced nobody knew that this technology is going to create such an environmental catastrophe. Even the Nobel Prize awarding organization was not aware of this while awarding Nobel Prize to Norman Borlaug. Also several world agencies bestowing awards/rewards to several politicalscientists like Dr. M.S.Swaminathan from India.

We must not forget the fact that GM technology also works under chemical inputs - irrigation only; and thus those impacts also apply to GM seed technology. In addition, GM seed technology presents several other impacts on biodiversity, contamination, re-generation, herbicide-tolerant weeds, new pests-diseases etc. Bt- technology was introduced to control bollworm but introduced new pink bollworm and to control this brought in terminator technology -- Roundup Ready Flex. Reddy (2000) said that it is like "scratching the head with fire". This destroys/eliminates the traditional agriculture/organic agriculture system in India, which is, thus, destroys the dry-land agriculture in India and making farmers permanently depend upon the MNCs for seeds.

In USA \& China GM crops were not permitted to grow in some zones. In India GM crops are grown everywhere including prohibited zones. There are several other aspects like food safety and ethics but India being a developing country has no mechanism to study such aspects. Thus, with the GM seed technology, the cure has become more dangerous than the disease. Two major components of agriculture have been gradually eroded, namely the extension services, State Seed production \& distribution system.

\section{Workable Green Revolution}

A workable green revolution or sustainable agriculture must be farming system based. To achieve this goal, governments must create a mechanism to collect traditional inventions of progressive farmers and integrate them into traditional technology that safeguards the environment and provide food safety, bio-safety, food and nutrient security (Figure 1). 


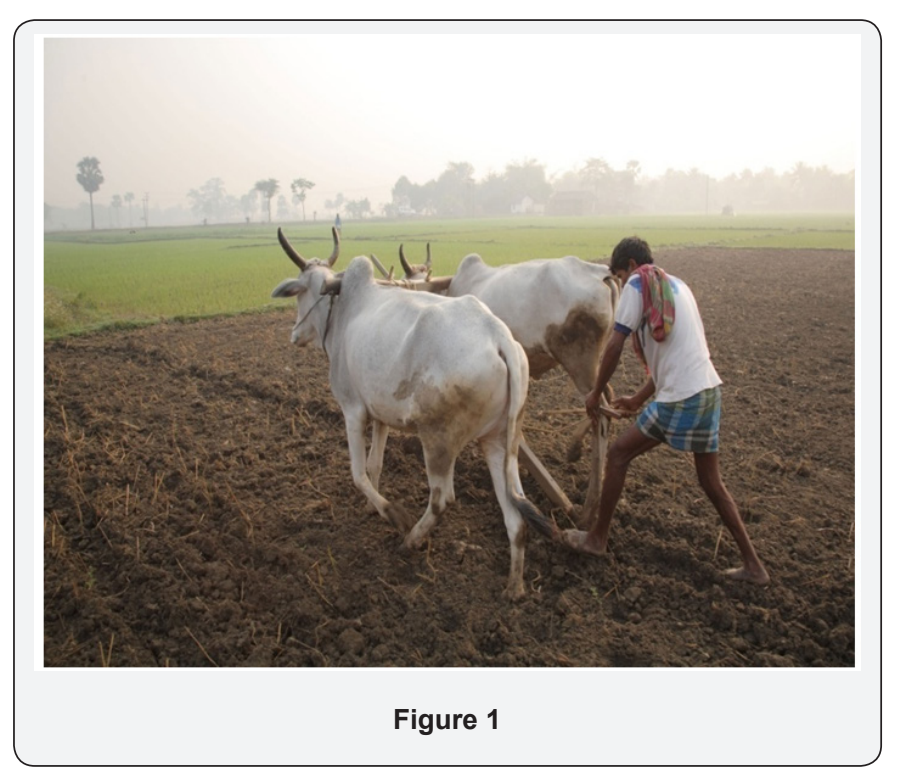

To achieve this, therefore, the governments must change the agricultural policy. It must include low input costs, pollutionfree quality food technology such as organic inputs under cooperative farming setup. This not only brings down the cost of production, improves the utilization of natural resources and put a full-stop to farmers' suicides. Better water management plays a crucial role by diversifying through less water intensive crops under climate change. We need crop rotation and intercropping systems to reduce the risk under cash crops. However, the success depends upon: better post-harvesting technologies including sufficient storage facilities, export facilities, transport facilities, food processing industries, better education and health care facilities, which might reduce the migration to urban centers. Need to establish commodity boards - already existing for some cash crops - with powers to regulate the area to be sown.

In fact progressive farmers with traditional wisdom have developed technologies and achieved far higher yields than the research station yields and received national and international awards/rewards and recognition but neither the government nor the scientists showed any interest, though there is a mechanism in government departments, to stabilize that technology and provide packages to farmers to achieve environmental friendly progress in agriculture.

In fact I included these in my Block Paper written to Counter Government's White Paper \& Vision 2020 document relating to Agriculture policy by Andhra Pradesh government, which was released in Assembly Press Gallery on 15th February 2001 by the opposition party. The government wanted to implement corporate agriculture in the state and for which the government implemented this in Kuppam. This was an utter failure. After the opposition came to power in 2004, prepared a document on cooperative farming but this was sabotaged by vested groups wherein introduced corporate mandate. I brought to the notice of the government and on which government stopped this proposal; and unfortunately the then Chief Minister died in an accidental accident (?) there were no further progress on this matter. Reddy (2018) discussed these issues in detail.

The two important components of agriculture are soil and climate, wherein climate is beyond human control and thus needs to adapt to it. Reddy (1993) presented adaptive measures for several countries including India, which is being used as reference book in post-graduate level in agricultural meteorology.

\section{References}

1. www.scribd.com/Google

2. Reddy SJ (2000) Andhra Pradesh Agriculture: Scenario of the last four decades. Secunderabad, India, p. 104.

3. Reddy SJ (2018) A Workable green revolution: Agriculture in the perspective of climate change", BSPubl., Hyderabad, India, p. 237.

\begin{tabular}{l} 
Your next submission with Juniper Publishers \\
will reach you the below assets \\
- Quality Editorial service \\
- Swift Peer Review \\
- Reprints availability \\
- E-prints Service \\
- Manuscript Podcast for convenient understanding \\
- Global attainment for your research \\
- Manuscript accessibility in different formats \\
( Pdf, E-pub, Full Text, Audio) \\
- Unceasing customer service \\
Track the below URL for one-step submission \\
https://juniperpublishers.com/online-submission.php \\
\hline
\end{tabular}

